\title{
カテゴリー判断課題におけるフランカー刺激が 意味飽和効果に及ぼす影響
}

\author{
下木戸隆司' 名古屋大学 \\ An influence of flanker in a category verification task \\ on semantic satiation effect
}

Takashi Shimokido (Nagoya University)

\begin{abstract}
This study examined semantic satiation in a flanked-category verification task. In the experiment, a target pair (FRUIT grape) was flanked by a distractor (i.e., flanker). There were three conditions; compatible condition in which flankers were semantically related to a target category word (FRUIT grape vs. apple), incompatible condition in which flankers were not related (FRUIT grape vs. coffee), baseline condition in which flankers were not presented. Seventy-three college students participated in the experiment and judged whether or not a instance word was related to a category word in the target pair. As a result, the semantic satiation effect was found regardless of flanker conditions. Additionally, the influence of flanker was not attenuated by prime repetitions. These results were elucidated in terms of decision criterion based on a semantic relatedness of prime and target instance words. A possibility indicated that the locus of decision criteria was shifted to a more careful one by prolonged prime repetitions. Finally, one explanation was discussed that an influence of satiation would be emerged from the process which suited semantic information to the context.
\end{abstract}

Key words: semantic satiation, category verification task, flanker effect, locus of response criterion.

The Japanese Journal of Psychology

2005, Vol. 76, No. 4, pp. 336-343

一つの語句を凝視し続けたり，何度も声に出したり していると，次第にそれが奇妙なものに思われ，まる でことばの意味が消えてしまったように感じられるこ とがある。意味飽和（semantic satiation）はこのよう な現象として知られ，ごく簡単な手続きによって意味 の消失が起きるという不思議さから, 古くから多くの 研究者を引きつけてきた。

また近年では，認知心理学の知見を適用して意味飽 和の研究が行われている。例えば，先行する語（プラ イム）が後続の語（ターゲット）と意味的に関連する 場合, ターゲットの処理が促進されることが知られて いる (Neely, 1991)。この効果が意味飽和の研究にと って重要なのは, プライムを長時間提示すると, 短時 間だけ提示していたときよりも，この意味的関連性の 効果が減じられることが繰り返し確認されているため

Correspondence concerning this article should be sent to: Takashi Shimokido, Department of Psychology and Human Developmental Sciences, Graduate School of Education and Human Development, Nagoya University, Furo-cho, Chikusa-ku, Nagoya 464-8601, Japan (e-mail:m47031a@cc.nagoya-u.ac.jp)

論文の作成にあたりご指導いただきました名古屋大学（現 所属：東京大学）岡田猛先生に感謝いたします。
である（Balota \& Black, 1997; Smith, 1984; Smith \& Klein, 1990)。そのことから, 意味的関連性効果の減 少（以後, 意味飽和効果と呼ぶ）は, 意味飽和の測度 としてょく利用されている。この効果に着目すること で，意味が消失するという特殊な現象がどのように生 起しているのか，その内的過程に焦点を当てた研究知 見が蓄積されつつある（Balota \& Black, 1997; Black, 2001; Kounios, Kotz, \& Holcomb, 2000; Pilotti, Antrobus, \& Duff, 1997)。

ところで，意味飽和はどのように生起すると考えら れるだろうか。これまでの説明では, 意味表象が減衰 するために意味が消失すると考えられることが多かっ た (Balota \& Black, 1997; Smith, 1984; Wertheimer \& Gillis, 1958)。つまり, 同じことばに長時間接触する ことで, 対応する表象に疲労や順応が生じ，表象の活 性が弱められたり，表象へのアクセスが阻害されたり する。このために意味飽和が起こると考えられた。こ の立場は直感的にわかりやすいこともあって, 古くか ら提唱されてきた。本研究では以後, この立場のこと を意味的抑制説と呼ぶことにする。

しかし意味的抑制説には問題もある。というのは, 
意味的関連性の効果が減じられ，抑制が生じたといっ ても，依然としてその効果が残っているからである。 意味的関連性効果は, ターゲットの意味情報の利用可 能性を反映しているという見解もあることから，この 効果が存在している限りは, ターゲットの意味情報は あらかじめ, ある程度利用可能な状態になっていたと 考えられる。なぜ意味情報が利用可能になっているの にもかかわらず, 意味の消失が意識的に感じられてし まうのだろうか。それに加えて, 同じ語に長時間接触 していることで意味が消失するどころか, むしろ新た な意味が付与される場合があることが報じられている (佐藤，1969）。なぜ意味表象に生じた抑制がこのよう な意味生成をもたらすのだろうか。意味的抑制説で は, これらの問題に対してほとんど言及がなされてい ない。

一方，意味の消失は利用可能な意味情報をうまく統 合できなくなったために生じると考えることも可能で ある。つまり意味飽和の影響は, 意味アクセスが行わ れた後の処理段階で現れると仮定することもでき, 本 研究ではこれを意味的拡散説と呼ぶことにする。

この立場によれば，同じことばに長時間接触するこ とによって影響を被るのは, 意味表象の活性やアクセ ス速度ではなく, むしろ紛らわしい意味表象を抑制 し, 最終的に一つのものとして同定する段階であると 考える。同じ語に接触し続けることで活性化の拡散が 進行するため, その語に対応する意味表象だけでな く, 意味的に関連した他の意味表象の影響も強くな る。関連する表象が競合しあうことで意味のまとまり が崩れ, 結果的に意味の消失が起こると考えるわけで ある (下木戸, 2003)。意味的関連性の効果を意味ア クセス後の処理過程に帰属する見方もあることを考慮 すれば (Balota \& Lorch, 1986; Seidenberg, Waters, Sanders, \& Langer, 1984), 同じことばに長時間接触す ることの影響がこの処理段階で生じるというのもあり うることである。

またこの立場では, 同じことばに長時間接触するこ とで, 意味表象の活性低下やアクセス遅延が生じるこ とを仮定しなくてすむので, 先に意味的抑制説のとこ ろで取り上げた問題をうまく説明することができる。 意味生成の問題についても, 競合する意味表象の一つ が優勢となり, 意識の上に現れたと考えれば何ら不思 議ではない。

このように意味的拡散説には利点もあるが，意味的 拡散説の方が妥当であるとする決定的な証拠が得られ ていないという問題もある。このため現時点では, 両 者の立場のどちらが妥当なのかを慎重に見極める必要 がある。

そこで本研究では, 両者の立場を識別するために一 つの観点を設定する。具体的には，ターゲット処理を 妨害する刺激（フランカー）をターゲットの上下に隣
Table 1

Example of target pair and flanker stimuli used in the experiment

\begin{tabular}{lll}
\hline Related & Unrelated & None \\
\hline apple & coffee & \\
FRUIT grape & FRUIT grape & FRUIT grape \\
apple & coffee & \\
\hline
\end{tabular}

接させて提示する (Table 1 参照)。このような状況 では, ターゲットとフランカーが意味的に関連しない 条件の方が，意味的に関連する条件や，フランカーと して非単語やアスタリスクが表示される中性条件より も, ターゲットに対する反応が遅れることが知られて いる (Flowers \& Wilcox, 1982; Shaffer \& LaBerge, 1979)。

フランカーの影響がプライムを長時間提示すること でどう変化するのかについて, 以下の予想が成り立 つ。もし意味的抑制説が仮定するように，プライムを 長時間提示することで意味ネットワークに抑制が生じ るのであれば，プライムと関連する表象にもそれが波 及するはずである。そのため長時間プライムを提示し た場合には，そうでない場合と比べ，プライムと意味 的に関連するフランカーの影響力は緩和されると想定 される。抑制が生じることでターゲットの活性が下が り,アクセス速度も遅くなるので, プライムとターゲ ットが意味的に関連する際の促進効果も, プライムと は意味的に関連するものの, ターゲットとは関連しな いフランカーがターゲットに及ぼす干渉効果も, どち らも小さくなると考えられるためである。つまり意味 的抑制説では，プライムを長時間提示することで生じ る抑制の影響は, 促進効果にも干渉効果にも対称的に 現れると予測できる。

それに対して, 意味的拡散説では意味的関連性の効 果は減少するが，フランカーの干渉効果は減じられな いと予想される。意味的拡散説では，同じことばに長 時間接触することで意味ネットワーク内に抑制が生じ るのではなく，むしろ意味表象を一つに同定する段階 で抑制が生じると仮定する。ターゲットを認知する際 に，ターゲットと関連しているが，ターゲットそのも のではない他の意味表象を除外しにくくなると考えら れる。つまり，プライムとターゲットが意味的に関連 する場合, 長時間プライムを反復提示することで意味 的に関連する他の余計な表象を抑えることが困難にな るので, 意味的関連性の効果は小さくなると想定でき る。

ところで, フランカーがターゲット処理に干渉する のは，フランカーとターゲットが意味的に関連しない 場合である。しかしフランカーの影響は, ターゲット 処理の比較的早い段階で現れると考えられるため 
(Mulder, Smid, \& Mulder, 1992; Smid, Lamain, Hogeboom, Mulder, \& Mulder, 1991), その干渉効果 はプライムを長時間反復提示することの影響をほとん ど受けないと予想される。というのは, 意味的拡散説 では，プライム反復の影響は文脈に適した意味表象を 同定するという比較的遅い段階で現れると想定される からである。このように意味的拡散説では, プライム を長時間提示することで生じる抑制の影響は，促進効 果に対してのみ現れ, 干渉効果に対しては現れないと 予想できる。

以上のように，フランカーによる干渉の影響がプラ イムの提示時間の長さによってどのように変化するの かに着目することで, 意味飽和が生じている際に何が 行われているのか, どちらの説明がより妥当なのかに 関して検討することが可能になると考えられる。

本研究では, フランカー付きカテゴリー判断課題を 用いて検討を行う。カテゴリー判断課題は，提示され たカテゴリー語（例：果物）と事例語（例：ブドウ） が同じカテゴリーに属するか否かを実験参加者に判断 させるものであり，意味飽和の研究ではよく用いられ ている (Balota \& Black, 1997; Pilotti et al., 1997; Smith, 1984; Smith \& Klein, 1990)。

また本研究では, 実験参加者がプライム提示中に夕 ーゲットを積極的に予測することで, 意味飽和効果が 消失してしまう可能性も考慮する（下木戸，2004）。 具体的には，プライム提示中に参加者がターゲットを 積極的に予測することを妨げるため，プライム（例： 果物）とターゲットのカテゴリー語が一致しないが, Yes 反応が要求される条件 (例: 楽器・ギター), 逆 にプライムとターゲットのカテゴリー語が一致する が, No 反応が要求される条件（例：果物・スリッ パ）を設定する。それに加え, 意味飽和効果の検出 が，実験で使用されるリストの構成に大きく左右され る点を考慮し (Black, 2001), フランカーの性質に応 じて三つの実験条件を設定する（Table 1参照）。

一つめの条件は, フランカー（例：リンゴ）と夕ー ゲットのカテゴリー語（例：果物）とが，常に意味的 に関連するものである。そのため, Y es 反応試行の夕 ーゲット対（例：果物・ブドウ）では，フランカーは 促進的に作用すると想定される。一方，No反応試行 のターゲット対（例：果物・スリッパ）では，フラン カーはターゲット対のカテゴリ一語とは意味的に関連 するものの, ターゲット対の事例語と関連しない。そ のため, ターゲット対の事例語がカテゴリー語に含ま れていないと正しく判断する際に，干渉的に作用する と想定される。

二つめの条件は, フランカー（例：コーヒー）と夕 ーゲットのカテゴリー語（例：果物）とが, 常に意味 的に関連しないものである。この場合, フランカーは Yes 反応試行のターゲット対（例：果物・ブドウ),
No 反応試行のターゲット対（例：果物・スリッパ） のどちらとも意味的に関連しないため, ターゲット対 のカテゴリー判断を行う際に干渉的に作用することが 想定される。

三つめの条件は, フランカーが提示されない条件で ある。この条件は, フランカーが実際に結果に影響し ていたのかを調べる際のベースラインとして機能す る。

フランカー付きカテゴリー判断課題を用いること で，具体的に検討される点は以下の通りである。まず Yes 反応試行において, 従来の研究と同様に意味飽和 効果が認められるかが検討される。その際, もし意味 的抑制説が妥当なのであれば，フランカーとターゲッ トのカテゴリ一語が意味的に関連しない条件の方が, 意味的に関連する条件やフランカーが提示されない条 件よりも意味飽和効果が大きくなると予想される。と いうのは，プライム反復によって関連性の効果が減じ られるのに対して, この条件ではフランカーはプライ ムとも意味的に関連しないので, フランカーの干渉効 果はプライム反復の影響を受けないと考えられるため である。長時間のプライム反復によって関連性の効果 が減少した状態に，フランカーの干渉効果が重なるた め, さらに関連性の効果が減じられる, つまり意味飽 和効果が大きくなると予測できる。

一方, 意味的拡散説では, 反復の影響は紛らわしい 意味表象を抑制し，最終的に一つのものとして同定す る段階で現れると考える。もしこれが妥当なのであれ ば，ターゲット対と意味的に関連しないフランカーの 影響はプライム反復の影響をそれほど受けないと予想 される。フランカーの影響と反復の影響は，それぞれ 異なる処理段階で現れることが想定されるためであ る。つまり, ターゲット対と意味的に関連しないフラ ンカーの影響はターゲット処理の比較的早い段階から 現れるのに対し，反復の影響はターゲット処理の比較 的後の段階で現れると考えられる。このようにフラン カーとターゲットのカテゴリー語が意味的に関連しな い条件の方が, 他の条件よりも意味飽和効果が大きく なるか否かに着目することで, 二つの立場からそれぞ れ異なった予想を引き出すことができる。

次にNo 試行においては, フランカーとターゲット のカテゴリー語が意味的に関連する条件で, フランカ 一の効果がプライム反復によって減じられるかが検討 される。もし意味的抑制説が妥当なのであれば, 長時 間プライムを反復することで意味ネットワーク内に抑 制が生じるため, プライムと関連するフランカーがタ ーゲットに及ぼす干渉効果は, フランカーとターゲッ トのカテゴリー語が意味的に関連しない条件やフラン カーが提示されない条件よりも小さくなると予想され る。

一方，意味的拡散説では，フランカーの干渉効果は 
長時間プライムを反復してもほとんど影響されないと 予想される。この立場では, フランカーの干渉効果と プライムの反復効果は, それぞれ異なった段階で別々 に影響すると考えるので, フランカーと反復の交互作 用を想定しないからである。ここでも，フランカーの 干渉効果がプライム反復によって減じられるか否かに 着目することで, 二つの立場から異なる予想を引き出 すことができる。

実験では,これらの予想について検討を行う。

\section{方 法}

実験参加者 成人男女 73 名が実験に参加した。

実験計画 以下の三つの要因が設定された。第 1 の 要因はプライムとターダット対の関連性に関する要因 であり, 反復提示されるプライム（例：果物）とター ゲット対のカテゴリー語が一致する条件 (例：果物) と一致しない条件（例：楽器）の 2 水準であった。第 2 の要因はプライムの反復提示回数に関する要因であ り, プライムを 3 回提示する条件と 30 回提示する条 件の 2 水準であった。第 3 の要因は, フランカーに関 する要因であり, 具体的には, ターゲット対のカテゴ リー語とフランカーが意味的に関連する条件と意味的 に関連しない条件，フランカーが提示されない条件 (統制条件) の 3 水準であった。これらの要因のうち, 最初の二つは個人内要因として, フランカーの要因に ついては個人間要因とした。

装置 刺激の提示, 反応の測定を含めた実験制御に はパーソナル・コンピュータ（NEC PC-9821Xs）お よび 15 インチ・ディスプレイ (Mitsubishi RD15DII) を使用した。一文字当たりの大きさは視角で約 0.7 度 $\times 0.9$ 度であった（観察距離約 $50 \mathrm{~cm}$ )。

刺激材料 下木戸（2003）が使用したリストをもと にカテゴリー語 32 語, 事例語 128 語を刺激として選 択した。このリストでは, カテゴリ一語は普段よく目 にする表記が用いられたが（文字数， $M=2.2$, Range =1-4), 事例語には仮名表記が用いられた（文 字数, $M=3.6$, Range=2-6)。プライム刺激はカテゴ リー語で構成され，ターゲット刺激はカテゴリ一語と 事例語の対で構成された。フランカー刺激は事例語に よって構成された。これらの刺激は 32 セットずつ, 計 12 のリストに振り分けられた。これらのリストは フランカーの性質に応じて, フランカーとターゲット 対のカテゴリ一語が意味的に関連するもの, 意味的に 関連しないもの，フランカーが含まれないものの三つ に分けられた。実験ではこれらのなかから二つのリス トが使用された。

リストに含まれる刺激の半数はターダット対の事例 語がカテゴリー語に含まれる Y es 反応対であり, 残 りの半数がカテゴリー語に含まれないNo 反応対であ つた。これらの反応対のさらに半数がプライムとター
ゲットのカテゴリー語とが一致する組み合わせであ り，残りが一致しない組み合わせであった。刺激りス トの順序および各条件へのリストの割り当ては個人間 でカウンターバランスされた。

手続き 実験は各個人に対して個別に行われた。プ ラス記号で構成される注視点列が 1 秒間画面中央に提 示され, $200 \mathrm{~ms}$ のブランクを挟んだ後, 条件が定め る回数だけプライム刺激が画面中央に反復提示され た。それぞれのプライムは $500 \mathrm{~ms}$ 提示された後, 画 面上から消去され，200 ms のブランクを挟んでから 再提示された。最後の刺激提示の際には夕ーゲット刺 激の提示を予告するシグナルとしてビープ音が $60 \mathrm{~ms}$ 鳴らされた。実験参加者はプライムを声に出して音読 するように，また途中でビープ音が聞こえたら，その 1 秒後に提示されるターゲットに備えるようにとあら かじめ教示されていた。続いてカテゴリ一語と事例語 からなるターゲット対とが空白（視角で約 0.7 度）を 挟んで画面中央に提示された。その際, フランカーが 提示される条件では, フランカーがターゲット対の上 下の位置（視角で約 1.8 度）に提示された。参加者は そこでターゲット対の事例語がカテゴリー語に含まれ るのか, それとも含まれないのかの判断をマウスのボ タンを押すことによって行った。具体的には, ターゲ ット対の事例語がカテゴリー語に含まればマウスの Y es のボタンを，そうでなければNoのボタンをでき るだけはやく，かつ正確に押すように求められた。ま たフランカーが提示される条件では, 参加者はフラン カーを無視するようにあらかじめ教示されていた。参 加者がいずれかのボタンを押し, 反応時間と反応ボ夕 ンが取得されるとともにターゲット刺激は消え，2秒 のインターバルをおいて次の試行に移った。なおマウ スの Yes ボタンと No ボタンの割り当ては個人間でカ ウンターバランスされた。

実験参加者は最初に練習試行を行った後, 64 試行 からなる本試行に入った。本試行で与えられる刺激の 順序は同一の反復刺激提示条件下のものが 3 回以上連 続して出現しないように, 個人ごとにランダムに並び 替えられた。また本試行は 32 試行ずつ二つのセッシ ヨンに分割され，セッションの間には 2 分間の休数が 挟まれた。

\section{結 果}

反応時間には対数変換が, 誤反応率には逆正弦変換 が施された後, 統計処理が行われた。誤反応を示した 試行は反応時間の分析からは除外した。また教示を明 らかに誤解していた 1 名の実験参加者のデータについ ても分析から除外した。各条件における反応時間の幾 何平均值と幾何標準偏差, および誤反応率を Table 2 に示す。

本研究では, 意味飽和の指標となる関連性 $\times$ 反復の 
Table 2

Geometric mean reaction times with standard deviations (in parentheses) and percent errors in the experiment

\begin{tabular}{|c|c|c|c|c|c|c|}
\hline \multirow{2}{*}{$\begin{array}{c}\text { Condition } \\
\text { (target pair vs. flanker) }\end{array}$} & \multicolumn{3}{|c|}{3 repetitions } & \multicolumn{3}{|c|}{30 repetitions } \\
\hline & RT & $(S D)$ & $\%$ errors & RT & $(S D)$ & $\%$ errors \\
\hline \multicolumn{7}{|l|}{ Related (FRUIT grape vs. apple) } \\
\hline Congruent & 682 & $(1.27)$ & 1.0 & 727 & $(1.28)$ & 2.1 \\
\hline Incongruent & 900 & $(1.26)$ & 10.4 & 888 & $(1.28)$ & 13.5 \\
\hline Difference & 218 & & 9.4 & 161 & & 11.4 \\
\hline \multicolumn{7}{|l|}{ Unrelated (FRUIT grape vs. coffee) } \\
\hline Congruent & 737 & $(1.21)$ & 1.0 & 784 & $(1.25)$ & 4.7 \\
\hline Incongruent & 945 & $(1.19)$ & 15.6 & 934 & $(1.19)$ & 14.1 \\
\hline Difference & 208 & & 14.6 & 150 & & 9.4 \\
\hline \multicolumn{7}{|l|}{ None (FRUIT grape) } \\
\hline Congruent & 607 & $(1.18)$ & 2.1 & 663 & $(1.17)$ & 1.0 \\
\hline Incongruent & 819 & $(1.15)$ & 18.8 & 812 & $(1.16)$ & 9.4 \\
\hline Difference & 212 & & 16.7 & 149 & & 8.4 \\
\hline \multicolumn{7}{|l|}{ Related (FRUIT slippers vs. apple) } \\
\hline Congruent & 753 & $(1.24)$ & 4.7 & 781 & $(1.25)$ & 4.2 \\
\hline Incongruent & 868 & $(1.27)$ & 4.7 & 907 & $(1.28)$ & 3.1 \\
\hline Difference & 115 & & 0.0 & 126 & & -1.1 \\
\hline \multicolumn{7}{|l|}{ Unrelated (FRUIT slippers vs. coffee) } \\
\hline Congruent & 807 & $(1.22)$ & 2.1 & 846 & $(1.20)$ & 2.6 \\
\hline Incongruent & 976 & $(1.20)$ & 5.7 & 977 & $(1.20)$ & 6.3 \\
\hline Difference & 169 & & 3.6 & 131 & & 3.7 \\
\hline \multicolumn{7}{|l|}{ None (FRUIT slippers) } \\
\hline Congruent & 674 & $(1.18)$ & 3.6 & 715 & $(1.21)$ & 2.6 \\
\hline Incongruent & 810 & $(1.21)$ & 7.3 & 843 & $(1.21)$ & 6.3 \\
\hline Difference & 136 & & 3.7 & 128 & & 3.7 \\
\hline
\end{tabular}

交互作用が Yes 反応試行と No 反応試行とで認められ るかに関心があるため，以後の分析では両者を分けて 吟味する。

Yes 反応試行 まず反応時間に関して分散分析を試 みたところ，関連性の主効果が有意であった（ $F(1$, 69) $=567.44, p<.001)$ 。つまりプライムとターゲット のカテゴリ一語が一致している条件の方が, 一致して いない条件よりも反応がはやかった。反復の主効果も 有意であり, プライムを 30 回提示した条件の方が 3 回提示した条件よりも反応が遅くなっていた（ $F(1$, 69) $=13.08, p<.001)$ 。フランカーの主効果も有意で あったため $(F(2,69)=4.43, p<.05)$, Tukey 法によ る多重比較を行ったところ，フランカーとターゲット 対のカテゴリ一語が意味的に関連しない条件は，フラ ンカーが提示されない条件よりも反応が遅くなってい た $(p<.05)$ 。他の条件間には有意差は認められなか つた。

また関連性 $\times$ 反復の交互作用が有意であり（ $F(1$, $69)=27.9, p<.001)$, 意味飽和効果が認められた。単
純主効果の検定を行ったところ，プライムとターゲッ トのカテゴリー語が一致している条件ではプライムを 30 回提示した条件の方が 3 回提示した条件よりも反 応が遅くなっていた $(F(1,138)=39.17, p<.001)$ 。 プライムとターゲットのカテゴリー語が一致していな い条件では両者に差は認められなかった（ $F(1$, $138)<1, n s)$ 。関連性 $\times$ フランカーの交互作用 $(F(2$, $69)=1.42, n s)$, 反復 $\times$ フランカーの交互作用 $(F(2$, $69)<1, n s)$, 関連性 $\times$ 反復 $\times$ フランカーの交互作用 $(F(2,69)<1, n s)$ はすべて有意ではなかった。

誤反応に関して分散分析を行ったところ, 関連性の 主効果が有意であり，プライムとターゲットのカテゴ リ一語が一致している条件の方が，一致していない条 件よりも誤反応が少なかった $(F(1,69)=61.03, p<$ $.001)$ 。反復の主効果 $(F(1,69)<1, n s)$, フランカー の主効果 $(F(2,69)<1, n s)$ はともに有意ではなか った。

また反復 $\times$ フランカーの交互作用が有意であったた め $(F(2,69)=4.28, p<.05)$, 単純主効果の検定を行 
ったところ，フランカーが提示されない条件でのみ， プライムを 30 回提示したときの方が 3 回提示したと きよりも誤反応が少なくなっていた $(F(1,69)=7.38$, $p<.01)$ 。ランカーとターゲットのカテゴリー語が 意味的に関連する条件や関連しない条件では, 反復の 効果に差は見られなかった（ともに $F(1,69)<1$, $n s)$ 。関連性 $\times$ 反復の交互作用 $(F(1,69)=3.48$, $n s)$, 関連性 $\times$ フランカーの交互作用 $(F(2,69)<1$, $n s)$, 関連性 $\times$ 反復 $\times$ フランカの交互作用 $(F(2$, 69) $=2.08, n s)$ はすべて有意ではなかった。これら の結果と反応時間で見られた傾向を比較したところ, はやさと正確さのトレードオフを強く疑わせるような 結果は得られなかった。

No 反応試行 反応時間に関して分散分析を行った ところ, 関連性の主効果が有意であった $(F(1,69)=$

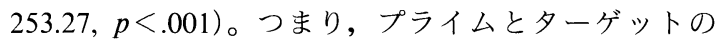
カテゴリー語が一致している条件の方が, 一致してい ない条件よりも反応がはやくなっていた。反復の主効 果も有意であり，プライムを 30 回提示した条件の方 が 3 回提示した条件よりも反応が遅くなっていた $(F(1,69)=15.07, p<.001)$ 。加えて, フランカーの 主効果も有意であったため $(F(2,69)=4.74, p<$ .05), Tukey 法による多重比較を行ったところ, フラ ンカーとターゲット対のカテゴリー語が意味的に関連 しない条件の方が, フランカーが提示されない条件よ りも反応が遅くなっていた $(p<.05)$ 。他の条件間に は有意差は見られなかった。

関連性 $\times$ 反復の交互作用 $(F(1,69)=1.81, n s)$, 関 連性 $\times$ フランカーの交互作用 $(F(2,69)<1, n s)$, 反 復 $\times$ フランカーの交互作用 $(F(2,69)<1, n s)$, およ び関連性 $\times$ 反復 $\times$ フンンーの交互作用 $(F(2,69)=$ $1.12, n s)$ はすべて有意ではなかった。

誤反応に関して分散分析を行ったところ，関連性の 主効果が有意であり, プライムとターゲットのカテゴ リー語が一致している条件の方が,一致していない条 件よりも誤反応が少なかった $(F(1,69)=9.16, p<$ $.01)$ 。反復の主効果 $(F(1,69)<1, n s)$, フランカー の主効果 $(F(2,69)<1, n s)$ は有意ではなかった。

また関連性 $\times$ フランカーの交互作用が有意であった ので $(F(2,69)=3.43, p<.05)$, 単純主効果の検定を 行ったところ, フランカーが提示されない条件 $(F(1,69)=8.20, p<.01)$ やフランカーとターゲット のカテゴリ一語が意味的に関連しない条件 ( $F(1$, 69) $=7.66, p<.01)$ で, 関連性の効果が見られた。具 体的には，プライムとターゲットのカテゴリー語が一 致しているときの方が一致していないときよりも誤反 応が少なくなっていた。プライムとターゲットのカテ ゴリー語が意味的に関連する条件では，このような関 連性の効果は認められなかった $(F(1,69)<1, n s) 。$ 関連性 $\times$ 反復の交互作用 $(F(1,69)<1, n s)$, 反復 $\times$
フランカーの交互作用 $(F(2,69)<1, n s)$, 関連性 $\times$ 反復×フランカーの交互作用 $(F(2,69)<1, n s)$ は すべて有意ではなかった。反応時間の傾向と比較した ところ, はやさと正確さのトレードオフを疑わせるよ うな結果は得られなかった。

\section{考 察}

本研究ではフランカー付きカテゴリー判断課題を用 いて, 長時間プライムに接触することで意味処理過程 にどのような影響が現れるのかに着目して検討を行っ た。その結果, Yes 反応試行ではフランカーの性質に かかわらず，すべての条件で関連性 $\times$ 反復の交互作用 が見られ，意味飽和効果が確認された。つまり，プラ イムとターゲットのカテゴリー語が一致する場合に, プライムを 30 回提示したときの方が 3 回提示したと きよりも反応が遅くなっていた。この結果は Smith \& Klein（1990）と整合的である。

まず注目すべきは, Y es 試行において, フランカー とターゲットのカテゴリー語が意味的に関連しない条 件での意味飽和効果が, 意味的に関連する条件やフラ ンカーが提示されない条件よりも大きくならなかった ことである。意味的抑制説が妥当なのであれば, 夕ー ゲットとフランカーが意味的に関連しない条件におい ては, 意味的に関連する条件と比べ, プライムを長時 間反復することで関連性の効果の減少が大きくなると 予想される。長時間のプライム反復によってターゲッ トの活性低下やアクセス遅延が生じているところに， フランカーの干渉効果が重なることで, ターゲット処 理のアドバンテージがさらに減殺されると考えられる からである。しかし本研究の結果は, この予測を支持 しなかつた。

次に注目されるのは, No 反応試行において, フラ ンカーとターゲットのカテゴリー語が意味的に関連す る条件でのフランカーの干渉効果が, プライム反復に よって減じられなかったことである。もし意味的抑制 説が仮定するように，プライムを長時間提示すること で意味表象の活性低下やアクセス遅延が生じるのであ れば，プライムを 3 回提示したときよりも，30回提 示したときの方がフランカーの干渉効果は小さくなっ たはずである。プライムと意味的に関連する限り，そ れがフランカーであれ，ターゲットであれ，意味ネッ トワーク内に生じる抑制の影響を被るためである。し かしながら本研究では, プライム反復によるフランカ 一効果の減少は認められなかった。

一つの可能性として考えられるのは, フランカーが 結果にあまり影響していなかつたため, 意味的抑制説 が予想するような傾向が認められなかったというもの である。しかし本研究ではフランカーの主効果が見出 されており, 効果自体の大きさ $(133 \mathrm{~ms})$ も他の研究 よりも大きいことから，この可能性は低いといえるだ 
ろう。

以上の点を考慮すると, 本研究で得られた結果は意 味的拡散説加予想される方向と一致しており，この 立場を支持するものといえる。またこの結果は，カテ ゴリー判断課題を用いてフランカーの影響を検討した 一連の実験（下木戸，2000，2004）のものと共通して いる。プライムを長時間反復させてフランカーの干渉 効果がどう変化するかに着目した実験が行われたが, そこでも反復とフランカーの効果の間に交互作用は見 出されていないのである。統計的仮説検定の性質を考 慮すると，反復とフランカーの間に交互作用が認めら れないという結果 (null effect) から，直ちに意味的 拡散説の妥当性を断定してしまうことは慎まねばなら ないが，これらの結果のすべてにおいて，意味的抑制 説を積極的に支持するものが見られなかったという点 は重要であると考えられる。

意味的拡散説は，長時間プライムに接触することで ターゲットと関連した他の意味情報が次々に活性化さ れ，ターゲット処理に必要な情報を取捨選択しにくく なるために意味飽和が生じると想定している。同様の 考え方は Barch, Cohen, Servan-Schreiber, Steingard, Steinhauer, \& van Kammen（1996）にも見られる。 Barch et al. (1996) は, 統合失調症患者でプライミン グ効果が減少していた原因を意味的統合の処理段階に 帰属した。つまり，統合失調症患者は文脈にそぐわな い余計な情報を抑制させるのが困難なため, プライミ ング効果が隇少したのだと解釈した。この説明は意味 的拡散説による意味飽和効果の説明と類似して抢り, 統合失調症患者に見られる意味処理や思考の機能障害 と意味飽和との関連を探る上で興味深い。今後は精神 医学や神経心理学的観点を交えて, さらに検討してい くことが求められよう。

ところで，長時間のプライム反復の影響は具体的に どのようなかたちで結果に影響したと考えられるだろ うか。実験参加者は課題を行う際，プライム（例：果 物) とターゲット対（例：果物・ブドウ）の事例語が 意味的に関連するか否かをチェックし，その結果によ つて採るべき反応の比重を変えていたと考えられる (Balota \& Lorch, 1986; Seidenberg et al., 1984)。つま り参加者はプライムとターゲット対が関連していそう なら Yes 反応よりに基準を置き，関連していなさそ うであればNo 反応よりに置くという方略を採ってい たと推察される。実際, 実験後の内省で, 最初に夕一 ゲット対の事例語を見てからカテゴリー語の方を見る ようにしていたという報告も得られた。

本研究の実験結果を見る限り, 長時間のプライム提 示の影響は, 結果的にこの反応の比重を弱める方向で 働いたと解釈される。したがって，この方略が有利に 動いた状況（プライムとターゲット対のカテゴリー語 が一致する条件）では反復によって反応が抑制される
こととなり，不利に働いていた状況（プライムとター ゲット対のカテゴリー語が一致しない条件）では逆に 反応が促進されることになる。実際，反応時間の結果 を見る限り，以上に述べたような傾向が示されてい た。このように, 実験参加者はプライム反復によって 意味表象を最終的に一つに確定するのが困難になった ことで，基準位置をより慎重な方向に移動していたと 考えられる。

実験参加者の基準位置がプライムの反復回数によっ て変化し，それが結果に影響を及ぼすということは， 意味飽和研究におけるカテゴリー判断課題の卓越性 (Smith，1984）は割り引いてとらえる必要があること を意味する。Smith（1984）は，非意味的要因の影響 を受けやすい語彙判断課題は意味飽和の研究には適切 ではなく，カテゴリー判断課題の方が意味アクセスの 結果をとらえやすいため, より適していると主張し た。しかし本研究の結果を見る限り，カテゴリー判断 課題は意味アクセスの結果だけを忠実に反映している わけではなく，むしろ意味情報の統合や反応決定を含 む意味処理過程を総合的に反映していると考えるべき であろう。

また本研究の結果は, 意味表象に抑制が生じうる可 能性自体を否定するものではない。意味表象に抑制が 生じることと, 意味アクセス後の処理過程で抑制が生 じることとが複合して意味飽和が生起している可能性 も考えられる。長時間のプライム反復によって当該の 意味表象が幾分か弱められ，そのことで文脈にそぐわ ない他の意味表象を抑えることが困難になり, 意味飽 和が生じているのかもしれない。実際にこのようなか たちで意味表象に抑制が生じているのか，それを解明 していくためには, カテゴリー判断課題だけでは不十 分であるといわざるを得ない。今後は，意味アクセス 後の処理過程の影響が比較的小さいと考えられている 音読課題などを用いて, 多角的に吟味を行い, さらに 知見を重ねていきたい。

\section{引用文献}

Balota, D. A., \& Black, S. (1997). Semantic satiation in healthy young and older adults. Memory \& Cognition, 25, 190-202.

Balota, D. A., \& Lorch, R. F., Jr. (1986). Depth of automatic spreading activation: Mediated priming effects in pronunciation but not in lexical decision. Journal of Experimental Psychology: Learning, Memory, and Cognition, 12, 336-345.

Barch, D. M., Cohen, J. D., Servan-Schreiber, D., Steingard, S., Steinhauer, S. S., \& van Kammen, D. P. (1996). Semantic priming in schizophrenia: An examinaion of spreading activation using word pronuciation and multiple SOAs. Journal of Abnormal Psychology, 105, 592-601. 
Black, S. R. (2001). Semantic satiation and lexical ambiguity resolution. American Journal of Psychology, 114, 493-510.

Flowers, J. H., \& Wilcox, N. (1982). The effect of flanking context on visual classification: The joint contribution of interactions at different processing levels. Perception \& Psychophysics, 32, 581-591.

Kounios, J., Kotz, S. A., \& Holcomb, P. J. (2000). On the locus of the semantic satiation effect: Evidence from event-related brain potentials. Memory \& Cognition, 28, 1366-1377.

Mulder, G., Smid, H. G. O. M., \& Mulder, L. J. M. (1992). On the transfer of partial information between perception and action. In D. E. Meyer \& S. Kornblum (Eds.), Attention and performance $X I V$. Cambridge, MA: MIT Press. pp. 567-588.

Neely, J. H. (1991). Semantic priming effects in visual word recognition: A selective review of current findings and theories. In D. Besner \& G. W. Humphreys (Eds.), Basic processes in reading, visual word recognition. Hillsdale: Lawrence Erlbaum Associates. pp. 264-336.

Pilotti, M., Antrobus, J. S., \& Duff, M. (1997). The effect presemantic acoustic adaptation on semantic "satiation". Memory \& Cognition, 25, 305-312.

佐藤貴美子 (1969). 意味の変容の問題—いわゆる Semantic Satiation をめぐって—— 心理学研究, 40, 182-191.

(Sato, K. (1969). On the problem of change of meaning: Semantic satiation. Japanease Journal of Psychology, 40, 182-191.)

Seidenberg, M. S., Waters, G. S., Sanders, M., \& Langer, P. (1984). Pre- and postlexical loci of contextual effects on word recognition. Memory \& Cognition, 12, 315-328.

Shaffer, W. O., \& LaBerge, D. (1979). Automatic semantic processing of unattended words. Journal of Verbal Learning and Verbal Behavior, 18,
413-426.

下木戸隆司 (2000)。意味成分の拡散が意味飽和に及 ぼす影響 日本認知科学会第 17 回大会発表論文 集, $122-123$.

(Shimokido, T. (2000). An effect of diffusion of meaning on a semantic satiation. Proceedings of the 17th Annual Meeting of the Japanese Cognitive Science Society, 122-123.)

下木戸隆司 (2003)。二重語氣判断課題における意味 飽和の影響 心理学研究, 74, 45-50。

(Shimokido, T. (2003). The effect of semantic satiation on a double lexical decision task. Japanease Journal of Psychology, 74, 45-50.)

下木戸隆司 (2004)。意味的に関連する表象が意味飽 和に及ぼす影響 読書科学，48，50-60.

(Shimokido, T. (2004). The effects of semantically related representation on semantic satiation. Science of Reading, 48, 50-60.)

Smid, H. G. O. M., Lamain, W., Hogeboom, M. M., Mulder, G., \& Mulder, L. J. M. (1991). Psychophysiological evidence for continuous information transmission between visual search and response processes. Journal of Experimental Psychology: Human Perception and Performance, 17, 696-714.

Smith, L. C. (1984). Semantic satiation affects category membership decision time but not lexical priming. Memory \& Cognition, 12, 483-488.

Smith, L., \& Klein, R. (1990). Evidence for semantic satiation: Repeating a category slows subsequent semantic processing. Journal of Experimental Psychology: Learning, Memory, and Cognition, 16, 852-861.

Wertheimer, M., \& Gillis, W. M. (1958). Satiation and the rate of lapse of verbal meaning. Journal of General Psychology, 59, 79-85.

- 2003. 2.25 受稿, 2005. 5.14 受理一 